\title{
Race and Equality across the Law School Curriculum: The Law of Tax Exemption
}

David A. Brennen

University of Georgia School of Law, brennend@uga.edu

D. SSRN

\section{Repository Citation}

David A. Brennen, Race and Equality across the Law School Curriculum: The Law of Tax Exemption (2004),

Available at: https://digitalcommons.law.uga.edu/fac_artchop/358

This Article is brought to you for free and open access by the Faculty Scholarship at Digital Commons @ University of Georgia School of Law. It has been accepted for inclusion in Scholarly Works by an authorized administrator of Digital Commons @ University of Georgia School of Law. Please share how you have benefited from this access For more information, please contact tstriepe@uga.edu. 


\title{
Race and Equality Across the Law School Curriculum: The Law of Tax Exemption
}

\author{
David A. Brennen
}

What is the relevance of race to tax law? The race issues are apparent when one studies a subject like constitutional law. The Constitution concerns itself explicitly with such matters as defining rights of citizenship, allocating powers of government, and determining rights with respect to property. Given the history of our country-with slavery followed by periods of de jure and de facto racial discrimination-these constitutional law matters obviously must have racial dimensions.

Tax law, however, does not generally concern itself explicitly with matters of race. Tax law is often thought of as completely race neutral in that its rules do not explicitly hinge tax consequences on matters related to race. In fact, even though the Internal Revenue Code refers to discrimination based on nonrace factors twenty-six times, ${ }^{1}$ it expressly ${ }^{2}$ refers to the concept of racial discrimination only twice, once with regard to racial discrimination by taxexempt social clubs ${ }^{3}$ and once with regard to the foreign tax credit for taxpayers that participate in international boycotts that promote racial discrimination. ${ }^{4}$ But despite the paucity of express racial references in the code itself, there are a myriad of implicit racial issues in tax law that mostly concern

David A. Brennen is the Ellison C. Palmer professor of tax law at Mercer University.

This article is written in memory of Jerome McCristal Culp Jr. I thank my wife, Kimberly Turner Brennen, for her support during its preparation.

1. The Internal Revenue Code refers to discrimination on the basis of financial status 19 times, see I.R.C. $\$ \$ 45 F, 79,105,117,120,125,127,129,132,274,401,408,410,411,413,414,415$, $501,505,4976,4980(2004)$; international taxation 5 times, see I.R.C. $\$ \S 168,891,896,897$, 3305 (2004); school location 1 time, see I.R.C. $\$ 144$ (2004); and availability of evidence 1 time, see I.R.C. $\$ 4980$ B (2004).

2. By use of express or expressly, this article focuses on language contained in the text of the Internal Revenue Code, not on the way words are interpreted by courts or agencies. For instance, even though the language of section 501 (c) (3) of the code does not expressly prohibit racial discrimination by tax-exempt charities, the Supreme Court has interpreted the term charitable in that section as essentially meaning "not discriminatory against black people.” See Bob Jones Univ. v. United States, 461 U.S. 574 (1983).

3. See I.R.C. $\$ 501$ (i) (2004).

4. See I.R.C. $\$ 999(b)(2004)$. 
the federal tax imposed on individual income or wages. ${ }^{5}$ One well-known example is the racial bias inherent in the marriage penalty as a result of a combination of tax law rules and the lingering effects of slavery and postslavery discrimination against blacks. Though teachers of tax law are often quite familiar with this and with similar race issues related to the federal taxes imposed on individual income and wages, few are as familiar with the many ways in which race affects our understanding of tax laws that apply to organizations, particularly tax-exempt nonprofit organizations. This article focuses exclusively on the law of tax exemption (familiarly known as "tax exempt law"), attempting to explain many of the instances in which race $^{6}$ is relevant to an understanding of this growing area of legal study. ${ }^{7}$

This article is divided into three parts. The first part discusses the longrunning examination of race in areas like constitutional law where it is obviously linked. The second part turns to race discussion in tax law, demonstrating that much of the racial focus in tax law has been on race bias in federal taxes imposed on individual income and wages. The third part outlines ways in which race can be discussed in a particular area that has yet to receive a full examination of race issues-tax exempt law. It shows that issues of racial

5. For articles that discuss race and tax law generally, see Beverly I. Moran \& William Whitford, A Black Critique of the Internal Revenue Code, 1996 Wis. L. Rev. 751; Dorothy A. Brown, Race, Class, and Gender Essentialism in Tax Literature: The Joint Return, 54 Wash. \& Lee L. Rev. 1469 (1997) [hereinafter Brown, Race, Class, and Gender]; Dorothy A. Brown, The Marriage Bonus/Penalty in Black and White, in Taxing America, eds. Karen G. Brown \& Mary Louise Fellows, 45 (New York, 1996); Karen B. Brown, Not Color- or Gender-Neutral: New Tax Treatment of Employment Discrimination Damages, 7 S. Cal. Rev. L. \& Women's Stud. 223 (1998); Mary Louise Fellows, Rocking the Tax Code: A Case Study of EmploymentRelated Child-Care Expenditures, 10 Yale J.L. \& Feminism 307 (1998); Laura Ann Foster, Social Security and African American Families: Unmasking Race and Gender Discrimination, 12 UCI.A Women's I.J. 55 (2001); Mary L. Heen, Welfare Reform, the Child Care Dilemma, and the Tax Code: Family Values, the Wage Labor Market, and the Race- and ClassBased Double Standard, in Taxing America, supra, at 322; Nancy C. Staudt, Taxing Housework, 84 Geo. L.J. 1571 (1996).

6. Although this article focuses only on race, other critical perspectives on tax exempt law might also be instructive. For instance, a provision that Congress enacted in 1976 prohibits race, color, and religious discrimination by tax-exempt social clubs but does not prohibit gender discrimination by these same organizations. See I.R.C. $§ 501$ (i) (2004). Certainly, a critical examination of this provision from a feminist perspective might reveal unacceptable gender bias in it. For other discussions of gender bias in the tax law generally, see Anne L. Alstott, Tax Policy and Feminism: Competing Goals and Institutional Choices, 96 Colum. L. Rev. 2001, 2004 (1996); Marjorie E. Kornhauser, A Legislator Named Sue: Re-Imagining the Income Tax, 5 J. Gender Race \& Just. 289 (2002) [hereinafter Kormhauser, A Legislator Named Sue]; Edward J. McCaffery, Taxing Women 5 (Chicago, 1997).

7. Tax exempt law is indeed a burgeoning area of study in law schools. Although there have long been treatises devoted to the subject (see, e.g., Frances R. Hill \& Douglas M. Mancino, Taxation of Exempt Organizations (Valhalla, 2002); Bruce R. Hopkins, The Law of TaxExempt Organizations (New York, 2003)), before 1995 there was no widely adopted casebook devoted to it. Between 1995 and 2003 there was only one casebook that focused significantly, though not exclusively, on tax exempt law: James J. Fishman \& Stephen Schwarz, The Law of Nonprofit Organizations (New York, 1995). In 2003 three new casebooks dealing exclusively with tax laws affecting tax-exempt organizations were published: Nicholas P. Cafardi \& Jaclyn A. Cherry, Tax Exempt Organizations: Cases and Materials (New York, 2003); James J. Fishman \& Stephen Schwarz, Taxation of Nonprofit Organizations: Cases and Materials (New York, 2003); Darryl K. Jones et al., The Tax Law of Charities and Other Exempt Organizations: Cases, Materials, Questions and Activities (St. Paul, 2003). 
discrimination, racial diversity, and racial perspectives might inform and improve certain aspects of tax exempt law. The article concludes that the expansion of legal scholarship and law teaching about race to such neutrallooking areas as tax exempt law can provide opportunities for discovery of new and likely better visions of tax law.

\section{Racial Bias in the Law Generally}

In his 1991 article, "Toward a Black Legal Scholarship," Jerome Culp takes a broad look at critical race theory and posits various ways in which discussions of racial justice can be injected into the law school curriculum and legal scholarship. ${ }^{8}$ Importantly, Culp's article articulates the relevance of a black perspective in law, that is, an approach to law-whether it be law making or legal analysis-which entails questioning what law would be like if black people played a more significant role in its creation or interpretation. For example, Culp imagines a Constitution and a Declaration of Independence written not only by whites (founding fathers and slave owners), but also by blacks (former slaves). Among his conclusions is that the original Constitution, as written and without the many amendments that followed, would probably not have been devoid of references to the history of black people as slaves in America if blacks had played a more significant role in its creation. Instead of a constitution that completely ignores the effects of slavery, Culp imagines, we would have one that fully reflects the interests of all citizens, explicitly referencing the deleterious impact of slavery on all of society. The essence of Culp's important work is that a black perspective in law necessarily leads to a different and socially more just legal environment.

Culp concludes his article by suggesting that tax law-like constitutional law-could be explored through a "colored" lens, possibly leading to new conceptions of justice and fairness in tax law. As he explains by means of a hypothetical conversation with his mostly white faculty colleagues:

There may be a income tax problem that would benefit from being viewed in a black perspective, but until you look, how will anyone know? To what extent have our tax laws been distorted now and historically by the question of slavery and continuing racism? Certainly taxation issues were included in the constitutional concerns about how slaves as property would be treated. ${ }^{9}$

According to Culp, even an area of law as apparently devoid of racial bias as tax law might look different if viewed critically from a black perspective. This does not mean that every tax law rule would necessarily change after critical race analysis; obviously, blacks and nonblacks have many of the same interests and desires. Culp simply means that a critical race analysis of tax law, as with all law, may reveal different visions of the law at places that might necessitate a different structure of specific provisions. But without such analysis these different visions may never become apparent.

8. Jerome McCristal Culp Jr., Toward a Black Legal Scholarship: Race and Original Understandings, 1991 Duke L.J. 39.

9. Id. at 101 . 


\section{Racial Bias in Tax Law}

In 1996, responding to Culp's suggestion that the concept of "black legal scholarship" be applied to tax law, Beverly Moran with coauthor William Whitford wrote an insightful article examining the code from a "black perspective." In "A Black Critique of the Internal Revenue Code," Moran offers an empirical analysis of social science data on race, income, and wealth to demonstrate the existence of racial bias with respect to four categories of tax benefits: wealth and wealth transfer benefits, home ownership benefits, employee benefits, and marriage benefits. As Culp imagined a constitutional convention including blacks, Moran imagines a black Congress and demonstrates that federal tax laws might be structured differently had blacks played a significant role in the creation of these laws. The differences would likely result from the intimate familiarity of black congresspersons with the perspective of black people in America. Like Culp, Moran recognizes that her hypothetical black Congress might have adopted some tax law provisions that look no different from those adopted by the mostly white actual Congress. But her analysis demonstrates that there are some areas of tax law that blacks have no interest in ${ }^{11}$ or that are biased against blacks, even when one controls for nonrace socioeconomic factors such as income. Though Moran cautions that a black Congress would not act solely in the interests of black people and would not be solely motivated to minimize taxes imposed on blacks, her black Congress metaphor effectively highlights a type of unconscious racism in certain aspects of American tax law. ${ }^{12}$

Later, in 1997, Dorothy Brown wrote a fascinating article that focuses on the different impact of the federal income tax laws on black women as compared to white women. "Race, Class, and Gender Essentialism in Tax Literature" examines three aspects of federal income tax law that adversely affect black families: the joint-return provisions, the exclusion from income of the value of services contributed by wives to their households, and the limited deductibility of childcare expenses. ${ }^{13}$ Prior scholars had intimated that these provisions of federal income tax law adversely affected women because women were "marginal wage or secondary earners." ${ }^{14}$ Scholars generally drew conclusions of gender bias from the salient fact that the typical household consists of a husband who is the primary wage earner and a wife who makes less as a

10. Sec Moran \& Whitford, supra note 5. Although many havc challenged the application of critical race theory to tax law (see, e.g., James D. Bryce, A Critical Evaluation of the Tax Crits, 76 N.C. L. Rev. 1687 (1998); Lawrence Zelenak, Taking Critical Tax Theory Scriously, 76 N.C. L. Rev. 1521 (1998)), critical race perspectives in tax law are indeed valuable. Notable examples are Beverly Moran's and Dorothy Brown's work exposing the marriage penalty as not only gender biased but also race biased. See Moran \& Whitford, supra note 5; Brown, Race, Class, and Gender, supra note 5.

11. See Moran \& Whitford, supra note 5, at 752-53 ("[A] Congress oriented solely to the interests of blacks would never have perceived the original wrong that income averaging was intended to cure.").

12. See Charles R. Lawrence III, The Id, the Ego, and Equal Protection: Reckoning with Unconscious Racism, 39 Stan. L. Rev. 317 (1987).

13. Brown, Race, Class, and Gender, supra note 5, at 1477.

14. Id. at 1471 . 
secondary wage earner. Brown uses empirical data to show that black households are not necessarily typical: black families are more likely than white families to have households in which the wages of husband and wife are roughly equal. And the gender bias literature that does not take account of race perpetuates the masking of race that Culp warns about.

The common theme among these examinations of race bias in federal tax law is their focus on how some specific provisions for determining an individual's federal wage and income tax liability tend to adversely affect black people. These critical race scholars take the current structure of the tax law and seek out instances in which that structure is biased against blacks. They do not argue that the biased aspects of tax law are proof that the members of Congress who enacted them were racists or that they purposefully discriminated against black people. Moran does not claim that the Internal Revenue Code is evidence of actionable racial discrimination by Congress. Nor does Brown claim that Congress intended to disadvantage black households more than white households when it enacted the joint-return provisions of the code in 1948. These scholars are simply bringing to light aspects of apparently neutral federal tax law provisions that have a biased impact on black taxpayers as compared to white taxpayers.

\section{Race Issues in Tax Exempt Law}

Another approach to examining race in tax law is to focus on issues of race pertaining to organizations that are exempt from the federal income tax. Tax exempt law is a subfield of tax law that focuses on the exemption from the federal income tax for corporations, trusts, and other entities (as opposed to individuals) that comply with certain statutory requirements. ${ }^{15}$ Tax-exempt organizations typically are charitable organizations, social welfare organizations, labor organizations, business leagues, social clubs, various beneficiary associations, certain insurance companies, cemetery companies, credit unions, employee benefit plans, and many more. The common link is that all of these organizations are not required to pay federal income tax so long as they abide by the relevant tax exemption rules. Tax exempt law consists of laws that enable tax-exempt organizations to maintain their nontaxable (i.e., taxexempt) status. Instead of focusing so much on the relative fairness (or unfairness) of a particular tax benefit as it affects blacks and whites, the race bias focus in tax exempt law is more on the justness (or unjustness) -with regard to blacks - of the statutory requirements for tax exemption.

This different focus in tax exempt law allows for a rich jurisprudential analysis of tax law. Indeed, one of the primary advantages of conducting an activity through a tax-exempt organization is that such activity automatically receives public and governmental financial support through tax expendi-

15. The exemption statute, quite succinctly, provides: "An organization described in subsection (c) or (d) or section 401 (a) shall be exempt from taxation under this subtitle unless such exemption is denied under section 502 or 503." 1.R.C. $\$ 501$ (a) (2004). 
tures. ${ }^{16}$ Scholars and judges disagree about the constitutional implications of government financial support by means of tax expenditures (tax benefits) as opposed to direct expenditures (direct outlays of cash).$^{17}$ But few could deny that many tax-exempt organizations receive a financial benefit from the government as a direct result of their tax-exempt status. The indirect financial support from government means that tax-exempt organizations often avoid many of the political aspects that accompany direct government spending. The uniqueness of tax exempt law issues, as compared to many issues that arise in individual income tax law for example, provides an opportunity to analyze tax exempt law and ask: How should the government allow tax-exempt organizations to use this indirect, but admittedly financial, government/ public benefit?

There are many ways in which racial issues present themselves in the field of tax exempt law. One major area-indeed, an area Culp alludes to in "Toward a Black Legal Scholarship"-involves examination of the Bob Jones University public policy doctrine and its application to racial preferences by tax-exempt charities. ${ }^{18}$ Given the current state of constitutional law doctrine concerning racial preferences, ${ }^{19}$ the issue of whether tax exempt law's public policy doctrine affects the ability of charities (private universities, for example) to engage in race-conscious affirmative action or award race-dependent scholarships to blacks is of paramount importance. ${ }^{20}$ In addition to the public policy doctrine, other racial issues include whether a charity's board of directors should be racially diversified if it is to represent a broad cross-section of the public that the charity serves ${ }^{21}$ and whether the current statutory

16. Tax expenditure theory essentially provides that the legal effect of certain tax benefits should be analyzed as if the government had provided the recipient of the tax benefit an equivalent grant of money. David A. Brennen, Tax Expenditures, Social Justice and Civil Rights: Expanding the Scope of Civil Rights Laws to Apply to Tax-Exempt Charities, 2001 B.Y.U. L. Rev. 167, 208-09 (2001). For a detailed discussion of tax expenditure theory, see Stanley S. Surrey, Pathways to Tax Reform: The Concept of Tax Expenditures 6-7, 30-49 (Cambridge, Mass., 1973); Stanley S. Surrey \& Paul R. McDaniel, Tax Expenditures 1-30 (Cambridge, Mass., 1985); see also Regan v. Taxation With Representation of Wash., 461 U.S. 540, 544 (1983).

17. See generally Linda Sugin, Tax Expenditure Analysis and Constitutional Decisions, 50 Hastings L.J. 407, 411 n.20 (1999); Edward A. Zelinsky, Are Tax "Benefits" Constitutionally Equivalent to Direct Expenditures? 112 Harv. L. Rev. 379, 380-81 (1998); see also Tex. Monthly, Inc. v. Bullock, 489 U.S. 1, 43 (1989) (Scalia, J., dissenting) ("[I]n other contexts we have suggested that tax exemptions and subsidies are equivalent. We have not treated them as equivalent, however, in the Establishment Clause context...." (citations omitted)).

18. See Culp, supra note 8, at 101; Bob Jones Univ. v. United States, 461 U.S. 574 (1983) (declaring that, because racial discrimination violates established public policy, a tax-exempt charity that discriminates against blacks is not entitled to 501 (c) (3) tax-exempt status).

19. See Grutter v. Bollinger, 539 U.S. 306 (2003); Gratz v. Bollinger, 539 U.S. 244 (2003).

20. See David A. Brennen, Charities and the Constitution: Evaluating the Role of Constitutional Principles in Determining the Scope of Tax Law's Public Policy Limitation for Charities, 5 Fla. Tax Rev. 779 (2002) [hereinafter Brennen, Charities and the Constitution]; David A. Brennen, The Power of the Treasury: Racial Discrimination, Public Policy, and "Charity" in Contemporary Society, 33 U.C. Davis L. Rev. 389 (2000); David A. Brennen, Race-Conscious Affirmative Action by Tax-Exempt 501 (c)(3) Corporations After Gmutter and Gratz, 77 St. John's L. Rev. 711 (2003) [hereinafter Brennen, Race-Conscious Affirmative Action].

21. Compare Steven A. Ramirez, A Flaw in the Sarbanes-Oxley Reform: Can Diversity in the Boardroom Quell Corporate Corruption? 77 St. John's I.. Rev. 837 (2003). 
prohibition on racial discrimination by tax-exempt social clubs should be expanded or otherwise changed..$^{22}$ Finally, in addition to racial discrimination, tax exempt law presents an opportunity to address race in the context of tax exemption rules that, though generally applicable to all tax-exempt organizations regardless of race, might look different if viewed through a "colored" lens. For example, some of the rules pertaining to political campaigning by tax-exempt charities (such as black churches) and tax-exempt charities that conduct community development activities (such as redeveloping blighted portions of an inner city) might look different if viewed from a critical race perspective.

\section{Racial Discrimination by Tax-Exempt Charities}

Of the many types of income tax exemptions described in the Internal Revenue Code, by far the most cherished is the tax exemption allowed for charitable organizations. At its most basic level, that exemption is the statutory relief from the obligation of a charitable organization to pay tax on annual income. Like all tax exemptions, this relief is granted pursuant to federal law and is given automatically to those organizations that apply for and are granted "charitable" status. ${ }^{23}$ But unlike just about all other tax-exempt organizations, charitable organizations receive special treatment as a direct result of their tax-exempt status. For instance, with few exceptions, charities are the only tax-exempt organizations that are also eligible to receive charitable contributions from the public that entitle the donor to federal income tax benefits. Individuals and corporations that donate money or property to charitable organizations may be entitled to receive a tax deduction when computing their own individual income tax liability. The potential deduction can be quite significant depending on the amount of the donation, the type of property donated, the income of the donor, and the type of charity to which the donation is given. This ability to receive tax-deductible donations from the public is a key federal tax law distinction between charities and other taxexempt organizations.

In addition to being excused from the requirement to pay tax on annual income, the charitable tax exemption opens doors to a variety of other economic and noneconomic benefits. Among the economic benefits are relief from the requirement to pay federal unemployment taxes, access to taxexempt government bonds, and eligibility for preferred postal rates. In addition to these direct economic benefits, tax-exempt charities are also eligible for many indirect economic benefits granted by state and local governments, including state and local income tax exemptions, state and local sales tax exemptions, and local real property tax exemptions.

A charitable organization must abide by many obligations to secure and maintain its tax-exempt status. The obligations stem directly from the tax law provision that authorizes the tax exemption for organizations performing

22. See I.R.C. $§ 501$ (i) (2004) (prohibiting racial discrimination by tax-exempt social clubs).

23. "Charitable" organizations are often referred to as 501 (c) (3) organizations, a reference to the section of the code which authorizcs the income tax exemption for charities. 
charitable activities. To be granted a charitable tax exemption, an organization must be

organized and operated exclusively for religious, charitable, scientific, testing for public safety, literary, or educational purposes, or to foster national or international amateur sports competition ..., or for the prevention of cruelty to children or animals, no part of the net earnings of which inures to the benefit of any private shareholder or individual, no substantial part of the activities of which is carrying on propaganda, or otherwise attempting, to influence legislation . . . , and which does not participate in, or intervene in ... , any political campaign on behalf of (or in opposition to) any candidate for public office. ${ }^{24}$

This statutory requirement imposes several affirmative and negative obligations on tax-exempt charitable organizations. Affirmatively, a tax-exempt charity must show that it is both organized and operated primarily for a proper charitable purpose. Negatively, a tax-exempt charity must avoid private inurement, cannot receive more than an insubstantial amount of private benefit, cannot engage in more than an insubstantial amount of legislative lobbying, and is prohibited from engaging in any political campaign activity.

The charitable purpose requirement is at the heart of the charitable tax exemption, imposing an obligation on the charity to have a special type of mission focus as opposed to a profit focus. The mission is distinctly different from the mutual-benefit mission of the many noncharitable tax-exempt organizations. The mission that constitutes a proper purpose for the charitable tax exemption must be what is collectively referred to as a charitable purpose. Some of these purposes are specifically delineated in the statute that authorizes the charitable tax exemption-religious and educational, for example. But many charitable purposes have to be gleaned from the statute by either the Internal Revenue Service or reviewing courts. Some purposes that have been recognized as "charitable" include providing relief to the poor, protecting the environment, combating community deterioration, providing homes for the elderly, and improving health.$^{25}$ All of these specifically recognized charitable purposes have at least one thing in common: they all seem to impart some benefit to the public. In fact, the requirement to provide a public benefit is integral to the many scholarly theories of charitable tax exemption. ${ }^{26}$

24. See I.R.C. $\$ 501$ (c) (3) (2004).

25. See generally Treas. Reg. $\$ 1.501$ (c) (3)-1(d) (2) (2004); see also Jones et al., supra note 7 , at 129-65.

26. See Rob Atkinson, Altruism in Nonprofit Organizations, 31 B.C. L. Rev. 501 (1990); Rob Atkinson, Theories of the Federal Income Tax Exemption for Charities: Thesis, Antithesis, and Syntheses, 27 Stetson L. Rev. 395 (1997); Boris I. Bittker \& George K. Rahdert, The Exemption of Nonprofit Organizations from Federal Income Taxation, 85 Yale L.J. 299 (1976); Evelyn Brody, Of Sovereignty and Subsidy: Conceptualizing the Charity Tax Exemption, 23 J. Corp. L. 585 (1998); Nina J. Crimm, An Explanation of the Federal Income Tax Exemption for Charitable Organizations: A Theory of Risk Compensation, 50 Fla. L. Rev. 419 (1998); Mark A. Hall \& John D. Colombo, The Charitable Status of Nonprofit Hospitals: Toward a Donative Theory, 66 Wash. L. Rev. 307 (1991); Mark A. Hall \& John D. Colombo, The Donative Theory of the Charitable Tax Exemption, 52 Ohio St. L.J. 1379 (1991); Henry Hansmann, The Rationale for Exempting Nonprofit Organizations from Corporate Income Tax, 91 Yale L.J. 54 (1981). 
A key question for the charitable tax exemption is how to determine whether a particular purpose is "charitable" or not. One instance in which the charitable purpose requirement can become conceptually difficult is when a proposed charitable purpose violates the public policy doctrine-a doctrine adopted by the Supreme Court and now incorporated in to tax-exempt-charity law. Pursuant to the public policy doctrine an organization that is otherwise "charitable" will not be treated as such if it engages in acts that contravene "clear" or "established" public policy. ${ }^{27}$ The prototypical example of an instance in which the public policy doctrine would defeat charitable status is racial discrimination against blacks. Accordingly, the Supreme Court affirmed the IRS revocation of charitable status for Bob Jones University, a nonprofit religious school that discriminated against blacks in its admission policies.

Administering the public policy doctrine, as applied to racial preferences against blacks, is not problematic. But the doctrine becomes much more difficult to administer in other instances. For example, should the public policy doctrine be applied in such a way as to deny charitable status to organizations that make racial preferences in the context of affirmative action? Though the Supreme Court recently ruled that affirmative action may be constitutional if race is one of many factors considered by a state actor, ${ }^{28}$ it also ruled that affirmative action is unconstitutional if race is a deciding factor. ${ }^{29}$ Thus, three tax exempt law issues that may be informed by a critical race perspective on racial preferences in the tax law arena are the following.

- Are the constitutional law standards for permissible racial preferences by state actors exactly the same as the tax exempt law standards for determining what is consistent with established public policy?

- If the tax exempt law standards are different from the constitutional law standards, how should they be defined?

- If the tax exempt law standards are not different from the constitutional law standards, how should one determine when a nonstate actor (a charitable organization) has a compelling "state"-like interest that would justify a racial preference?

One approach to the issue of racial discrimination by tax-exempt charities might be to say that the public policy doctrine prohibits all racial preferences whether for affirmative action purposes or not. But how would this analysis be altered if the racial preference issue were addressed by a hypothetical black Congress? Asked differently, might a black perspective on this issue yield a different legal result? A black perspective might suggest that, because racebased affirmative action aimed at benefiting society is meaningfully different from invidious racial discrimination against blacks, tax-exempt charities should

27. Bob Jones Univ. v. United States, 461 U.S. 574, 591 (1983) ("A corollary to the public benefit principle is the requirement, long recognized in the law of trusts, that the purpose of a charitable trust may not be illegal or violate established public policy.").

28. See Grutter v. Bollinger, 539 U.S. 306 (2003).

29. See Gratz v. Bollinger, 539 U.S. 244 (2003). 
be permitted to engage in affirmative action even in the face of the public policy doctrine. ${ }^{30}$

Perhaps one reason for this potential issue respecting the legality of affirmative action by tax-exempt charities is the manner in which the tax law rule aimed at combating discrimination-the public policy doctrine-was adopted by the Supreme Court in Bob Jones University $v$. United States. The only tax law issue involved in the case was whether a tax-exempt charity's discrimination against black people necessitated denial of the benefits that flow from the charitable tax exemption. But instead of creating a rule specific to invidious racial discrimination, the Court in BobJones University adopted a broad neutrallooking rule that, on its face and in a manner consistent with the entire Internal Revenue Code, does not even mention "race" or "discrimination." That is, it adopted a facially neutral tax law rule that could conceivably apply to any number of circumstances, some having to do with race and some having nothing at all to do with race. In other words, instead of expressly attempting to include the "black perspective and experiences" of marginalized applicants to Bob Jones University in tax exempt law, the public policy doctrine masks the racial dimensions of this area of law through adoption of an apparencly neutral tax law rule-the public policy doctrine.

\section{Racial Discrimination by Noncharitable Tax-Exempt Organizations}

Another example of an attempted masking of race in tax exempt law is Congress's adoption of a rule prohibiting racial discrimination by tax-exempt social clubs, ${ }^{31}$ which do not enjoy many of the "special" privileges bestowed upon tax-exempt charities. Tax-exempt social clubs are not eligible to receive tax-deductible contributions, nor are they entitled to the many state and nontax federal benefits reserved solely for tax-exempt charities. Nevertheless, tax-exempt social clubs are entitled to federal exemption from the income tax-so long as they comply with the statutory requirements contained in the portions of the tax exemption law specifically applicable to them.

A tax-exempt social club is a club "organized for pleasure, recreation, and other nonprofitable purposes, substantially all of the activities of which are for such purposes and no part of the net earnings of which inures to the benefit of any private shareholder." 32 Many private golf and tennis clubs are organized as tax-exempt social clubs so long as they comply with this definition. Many of these clubs have been known to discriminate against women and minorities, including blacks, and such discrimination continues even today. ${ }^{33}$ Responding

30. See Brennen, Charities and the Constitution, supra note 20; Brennen, Race-Conscious Affirmative Action, supra note 20.

31. See I.R.C. $\$ 501$ (i) (2004).

32. See I.R.C. $\$ 501$ (c) (7) (2004).

33. One widely publicized example of a non-tax-exempt golf social club that continues to exclude women is the Augusta National Golf Club in Georgia, home of the Professional Golf Association's Masters Golf Tournament. 
to racial discrimination at social clubs, Congress enacted a tax law provision in 1976 aimed at prohibiting such invidious acts. ${ }^{34}$

Though this nondiscrimination provision is certainly a step in the right direction toward prohibiting discrimination by tax-exempt social clubs, it clearly lacks a black perspective. Its legislative history says simply: "In view of national policy, it is believed that it is inappropriate for a social club or similar organization described in section 501 (c) (7) to be exempt from income taxation if its written policy is to discriminate on account of race, color or religion." 35 From a black perspective, one might wonder why this provision applies only to social clubs. Does this mean that racial discrimination by other tax-exempt organizations is permissible for tax law purposes? Although the public policy doctrine announced by the Supreme Court in Bob Jones University $v$. United States clearly prohibits racial discrimination by tax-exempt charities, that doctrine applies only to tax-exempt charities. The Bob Jones University public policy doctrine does not apply to the many other tax-exempt organizations described in the tax exemption statute.

Aside from the limited applicability of the nondiscrimination rule to taxexempt organizations other than social clubs, another race issue is why the rule, at least textually, is so restrictive. Indeed, the textual expression of the rule applies only to discrimination contained in a tax-exempt social club's written documents (the charter, bylaws, or other governing instrument, or any written policy statement). Does this mean that official and authorized discrimination by words or actions of key members of a tax-exempt social club cannot cause the organization to lose its federal tax exemption? This limited applicability to written documents is very different from the much broader public policy rule for tax-exempt charities, which presumably seeks out discrimination wherever it exists. A hypothetical black Congress today (or even in 1976 for that matter) would most certainly adopt a statute very different from the one actually adopted as a nondiscrimination rule for tax-exempt

34. See Act of Oct. 20, 1976, Pub. L. No. 94-568, 90 Stat. 2697. The statutory provision that prohibits discrimination by tax-exempt social clubs provides:

Notwithstanding subsection (a), an organization which is described in subsection (c) (7) shall not be exempt from taxation under subsection (a) for any taxable year if, at any time during such taxable year, the chatter, bylaws, or other governing instrument, of such organization or any uritten policy statement of such organization contains a provision which provides for discrimination against any person on the basis of race, color, or religion. The preceding sentence to the extent it relates to discrimination on the basis of religion shall not apply to-

(1) an auxiliary of a fraternal beneficiary society if such society-

(A) is described in subsection (c) (8) and exempt from tax under subsection (a), and

(B) limits its membership to the members of a particular religion, or

(2) a club which in good faith limits its membership to the members of a particular religion in order to further the teachings or principles of that religion, and not to exclude individuals of a particular race or color.

See I.R.C. $\$ 501$ (i) (2004) (emphasis added).

35. See S. Rep. No. 94-1318; 94th Congress, 2d Sess.; H.R. 1144 (1976). 
social clubs. ${ }^{36}$ A statute enacted by blacks would likely address discrimination by the many other categories of noncharitable tax-exempt organizations besides social clubs and would likely address discrimination in various forms, whether reflected expressly in written documents or not.

\section{Racial Diversity on Tax-Exempt Charities'Boards}

Another area of tax exempt law that could be influenced by a critical race perspective concerns the composition of the board of directors of a taxexempt charitable organization. Steven Ramirez's article on federal corporate law reform efforts aimed at lessening the likelihood of corporate scandals like those at the start of the millennium posits that a racially diverse board of directors would make such scandals less frequent. According to Ramirez, cultural and racial diversity on corporate boards "could enhance small group decision-making processes and diminish the inclination of small groups to devolve into a groupthink approach to issues. ${ }^{37} \mathrm{He}$ explains that groupthink causes small groups, like boards of directors, to mindlessly adhere to group norms and fail to challenge or question group decisions. Cultural diversity, which includes racial diversity, on corporate boards tends to discourage groupthink and reduce the risk of inappropriate decision making such as that at Enron. Though this racial diversity approach has been used in other countries in reforming corporate law rules, the United States failed to do so in its legislative response to the many corporate scandals that plagued American corporations.

Although Ramirez's assertions about the value of racial diversity on forprofit corporate boards are aimed at improving corporate financial performance, similar assertions about the value of diversity can be made without reference to the financial bottom line. Is there a value in diversity that does not depend on showing a financial or economic interest? Such claims about the noneconomic value of diversity can be made with respect to for-profit corporations but may not have as much force in a profit-motivated institution. The same is not true, however, for tax-exempt organizations-specifically, taxexempt charitable organizations. Because tax-exempt charities are mission driven and not profit driven, the value for them of racial diversity must necessarily be linked to something other than financial return. In fact, taxexempt charities are legally prohibited from improperly passing on organizational profits to shareholders or members. The beauty of tax exempt law with respect to race is that the race issues are not necessarily subject to being compromised by concern for the financial bottom line. ${ }^{38}$

Federal tax law does not contain any express provisions concerning laws generally applicable to boards of directors of tax-exempt organizations-a

36. Another obvious issue here is the noticeable absence of any mention of gender discrimination. Would a feminist approach, or for that matter any other approach to legal analysis that represents the interests of a marginalized segment of society, endorse a nondiscrimination law in this context that does not prohibit gender discrimination?

37. Ramirez, supra note 21 , at 839 .

38. The lack of a legal concern for profit does not mean that tax-exempt charities do not care about money. Like all nonprofit organizations, they must ensure that they have sufficient revenues to pay bills and, if appropriate, expand operations. 
matter left primarily to state law. But tax exempt law does require that the organizational structure of a tax-exempt organization be such that the organization is driven to accomplish its tax-exempt mission. ${ }^{39}$ This requirement is most prevalent with respect to tax-exempt charitable organizations. Two major concerns regarding the structure of tax-exempt boards that make tax exempt law open to a racial analysis are the requirement that board members avoid reaping improper financial benefits from the organization and the requirement that the board represent a broad cross-section of the community the organization serves.

Federal tax law prohibits tax-exempt charities' board members from receiving organizational profits except as beneficiaries or as fair compensation for products or services delivered to the charity by, or on behalf of, the particular board member. A board must constantly ensure that all transfers of money or property between the organization and a board member are consistent with this prohibition on improper private benefits. Ramirez's article on racial diversity's tendency to lessen the occurrence of groupthink on corporate boards suggests that a racially diverse tax-exempt charitable board would be less likely to engage in prohibited private benefit transactions. The idea is that a more diverse board creates a culture of scrutiny that encourages board members to speak out whenever improper activities occur. Accordingly, while racial diversity does not guarantee that improper private benefits will not pass from the tax-exempt charity to individual board members, it might lessen the likelihood of such improper deals. Ramirez's assertion with respect to forprofit corporate boards is that Congress made a mistake in not including a racial diversity mandate for corporate boards in the Sarbanes-Oxley legislation. A critical race perspective on tax exempt law might indicate that taxexempt charitable boards, even more than for-profit corporate boards, would likewise benefit from a racial diversity mandate.

Tax exempt law sometimes requires that a tax-exempt charity's board of directors represent a broad cross-section of the community served by the charity. ${ }^{40}$ This requirement is most exemplified in the context of the private foundation rules applicable to tax-exempt charitable organizations. A private foundation is a tax-exempt charity that either fails to serve certain specified charitable purposes or fails to demonstrate that it has appropriate levels of public financial support. Unless a charity serves certain educational, religious, medical, public safety, or governmental purposes, it must demonstrate that it receives substantial financial support from a wide array of public sources to

39. In the wake of the many corporate corruption scandals that have plagued the for-profit corporate environment, tax exempt law and nonprofit corporate law are beginning to focus more closely on specific corporate governance issues. See, e.g., Michael W. Peregrine et al., New EO Focus-The Board Compensation Committee, 43 Tax Exempt Org. Tax Rev. 265, 265-71 (2004). The American Law Institute has also instituted a project ("Principles of the Law of Nonprofit Organizations," Evelyn Brody, reporter) that is focused, in part, on legal issues specific to boards of directors of nonprofit organizations.

40. See, e.g., Rev. Rul. 83-157, 1983-2 C.B. 94. The Internal Revenue Service has ruled that a hospital that does not have an emergency room open to the poor may still qualify as charitable so long as it, among other things, has a diverse board. Id. See also Treas. Reg. $§$ $1.170 \mathrm{~A}-9$ (e) (3) (v) (1973) (relating to private foundation status for tax-exempt charities). 
avoid private foundation status. To satisfy the substantial financial support requirement, a tax-exempt charity must show either that it receives more than one-third of its support from a variety of public sources or that it receives more than ten percent of its support from these sources and satisfies other factors. Among the other factors is that the board of directors represent a broad crosssection of the community. ${ }^{41}$

Because it does not specifically state that racial diversity is required (or even contemplated) with respect to either the rules that limit private benefits or those that require a charity board to represent a broad section of the community, tax exempt law presents an opportunity to consider race. We might ask: To what extent might these two aspects of tax exempt law (prohibition of private benefits and broad cross-section of community) benefit from a race perspective? Should tax exempt law require, or at least urge, tax-exempt charities to have racially diverse boards in some cases? Further, should tax exempt law apply a racial diversity mandate for all tax-exempt organizations, not just tax-exempt charities? This article is not intended to answer these questions; it merely raises the issues. But, as Culp might say, how will we ever know if there is a race issue with respect to these aspects of tax exempt law unless we look through a colored lens?

\section{Other Areas That Might Benefit from a Black Perspective}

There are many other possibilities for legal education to consider race in the context of tax exempt law. Broadly speaking, many of these other areas involve looking not so much at explicit notions of racial discrimination or racial diversity, but more generally at how different structures of law affect certain racial populations. For instance, religion is a big part of the black experience and has been since the time of slavery, so laws that affect taxexempt black churches might have a special impact on the black community. Consider the rule that prohibits tax-exempt charities, including churches, from performing political campaign functions for political candidates. ${ }^{42}$ It is not uncommon for black churches to allow political candidates, especially those candidates who advocate the interests of black people in particular, to speak from the pulpit. Even though the no-political-activities prohibition is a

41. See I.R.C. $§ 170$ (b) (1) (A) (i-vi) (2004), Treas. Reg. $\$ 1.170 A-9(e)(3)$ (v) (1973). The "broad governing body" requirement provides:

The fact that an organization has a governing body which represents the broad interests of the public, rather than the personal or private interests of a limited number of donors . . . will be taken into account in determining whether an organization is "publicly supported." An organization will be treated as meeting this requirement if it has a governing body . . which is comprised of public officials acting in their capacities as such; of individuals selected by public officials acting in their capacities as such; of persons having special knowledge or expertise in the particular field or discipline in which the organization is operating; of community leaders, such as elected or appointed officials, clergymen, educators, civic leaders, or other such persons representing a broad cross-section of the views and interests of the community, or, in the case of a membership organization, of individuals elected pursuant to the organization's governing instrument or bylaws by a broadly based membership.

Treas. Reg. \$ 1.170A-9(e)(3) (v) (1973) (emphasis added).

42. See I.R.C. $\$ 501$ (c) (3) (2004). 
neutral-looking provision, a black perspective on this rule might result in a different interpretation of it to reflect the particular interests of black peopleor even result in a different rule.

Another example has to do with tax-exempt charities that engage in community development activities. A community development organization is a tax-exempt organization formed to develop areas of a community that are often blighted or otherwise subject to severe deterioration. Specifically, an organization formed for the purposes of relieving poverty, eliminating racial or ethnic prejudice, lessening neighborhood tensions, and combating community deterioration in economically depressed areas is entitled to taxexempt charitable status. To accomplish these purposes, community development organizations often involve partnerships between government and private developers (or other private interests) formed to provide funds to businesses and individuals who are not otherwise able to get funds because of the financial risk associated with operating in depressed communities or because of their minority or disadvantaged status. Charitable tax exemption granted to community development organizations could present an opportunity to explore tax exempt law's ability to recognize the uniqueness of being black in Amcrica. For example, the Internal Revenue Service has historically limited the community development tax exemption to organizations that "relieve poverty, eliminate prejudice, reduce neighborhood tensions, and combat community deterioration." 43 A race analysis of this aspect of tax exempt law might ask whether the law should permit a community development organization to exist if its only objective is to "eliminate discrimination" in a particular area of a community?

$$
* * * * *
$$

Issues of race pervade American law-not just constitutional law, but all law. If the aim of law is to seek out justice, it only makes sense that legal education provide an opportunity to study the racial and nonracial aspects of law with an eye toward correcting any injustice. Many injustices-again, racial and nonracial-are explicit and apparent. Many other injustices, though, are hidden from plain view. As Jerome Culp has pointed out, racial injustices are often so well hidden that it takes a special type of "vision," indeed a special type of experience, to discover them. Though many steps toward exposing race bias in tax law have been taken, there is still much work to do. Here, as in other aspects of American life, we still have a long way to go in stamping out the vestiges of slavery. A critical race examination of tax exempt law will get us just that much closer to achieving this laudable social justice goal. 